\title{
SUROWCE STRATEGICZNE W SYSTEMIE BEZPIECZEŃSTWA EKONOMICZNEGO KRAJU
}

\author{
Aleksander Szlachta, Andrzej Bujak \\ Wyższa szkoła Bankowa we Wrocławiu \\ Instytut Logistyki
}

\begin{abstract}
Streszczenie: Wysokie tempo rozwoju gospodarczego oraz bezpieczeństwa narodowego jakiegokolwiek kraju bez dostępu do potrzebnych gospodarce surowców jest niemożliwe. Pojęcie bezpieczeństwa ekonomicznego odnosi się do czynników stanowiących ekonomiczne podstawy funkcjonowania gospodarki państwa. W celu utrzymania niezakłóconego rozwoju gospodarki państwo tworzy rezerwy rzeczowe. Wyodrębnia więc określoną potrzebami część zasobów materialnych, którą gromadzi z przeznaczeniem dla realizacji szczególnych celów. W sytuacji szybko zmieniającej się rzeczywistości gospodarczej, zarówno w kraju, jak i na świecie, rezerwy strategiczne nabierają szczególnego znaczenia. Stanowią bowiem jeden z najważniejszych elementów bezpieczeństwa państwa. Zestaw strategicznych dla gospodarki surowców nie jest stały i ulega zmianom, w zależności od przyjętego modelu rozwoju, jak również od stopnia ich dostępności i potrzeb systemu obronnego. W światowej polityce gospodarczej w ostatnich latach często jako broń stosuje się rozgrywkę surowcami, a więc niemilitarne uderzenie osłabiające gospodarkę przeciwnika. Celem artykułu jest pokazanie kluczowej roli surowców strategicznych dla zapewnienia bezpieczeństwa narodowego, w tym i bezpieczeństwa ekonomicznego, a więc niezakłóconego rozwoju gospodarki kraju.
\end{abstract}

Słowa kluczowe: bezpieczeństwo narodowe, bezpieczeństwo ekonomiczne, konflikty gospodarcze, rezerwy strategiczne, surowce: strategiczne, krytyczne, deficytowe

DOI: $10.17512 /$ znpcz.2017.4.1.10

\section{Wprowadzenie}

Dostęp do potrzebnych gospodarce surowców jest jednym z czynników wpływających na tempo rozwoju gospodarczego, a w konsekwencji także i bezpieczeństwo narodowe kraju. W najszerszym znaczeniu bezpieczeństwo jest zjawiskiem subiektywnym, które można rozumieć jako brak zagrożeń. Bez dostępu do potrzebnych gospodarce i społeczeństwu surowców nie jest to możliwe do osiągnięcia. Problem stanowi nie tylko dostępność geograficzna i wielkość zasobów. Jest nim również polityka zachowania dominującej pozycji ekonomicznej na światowym rynku surowcowym przez kraje dysponujące określonymi (głównie energetycznymi) surowcami. Ograniczony dostęp poszczególnych państw do potrzebnych ich gospodarkom surowców, w tym szczególnie energetycznych, jest często przyczyną konfliktów międzynarodowych, głównie o charakterze politycznym, a niekiedy i militarnym. Wiele państw, aby zapewnić sobie niezakłócone dostawy niezbędnych surowców, decyduje się na wszelkie możliwe działania, nie wyłączając zbrojnych. 
Celem artykułu jest pokazanie kluczowej roli surowców strategicznych dla zapewnienia bezpieczeństwa narodowego, a w tym i bezpieczeństwa ekonomicznego, a więc niezakłóconego rozwoju gospodarki kraju.

\section{Bezpieczeństwo ekonomiczne}

Bezpieczeństwo narodowe jako kategoria społeczna jest oceną stopnia zaspokojenia podstawowych potrzeb człowieka, jak potrzeba istnienia, tożsamości, dobrobytu czy stabilności. Pojęcie bezpieczeństwa odnoszone jest również do zagrożenia dla narodowych wartości albo prawdopodobieństwa zachowania państwowości.

$\mathrm{W}$ określeniu kategorii bezpieczeństwa, podobnie jak w wielu innych kategoriach nauk społecznych, nie przyjęto dotąd jednej definicji. Bezpieczeństwo często określane jest jako:

- stan, to jest osiągnięte poczucie bezpieczeństwa konkretnego podmiotu;

- proces, to jest zapewnienie poczucia bezpieczeństwa określonego podmiotu, poprzez stawianie czoła wyzwaniom, redukowanie ryzyka i przeciwdziałanie różnego rodzaju zagrożeniom dla państwa i jego interesów (MON 1970, s. 761).

W najszerszym znaczeniu bezpieczeństwo jest zjawiskiem subiektywnym, które można rozumieć jako brak zagrożeń (nieobecność strachu). Sugeruje to osiągnięcie stanu uzyskanego w wyniku ochrony i obrony przed możliwymi zagrożeniami, wyrażonego stosunkiem potencjału obronnego do skali zagrożeń (Koziej 2011, s. 20). Pojęcie bezpieczeństwa należy interpretować w szerokim zakresie: obiektywnie, jako stan, który określają czynniki mierzalne, albo subiektywnie, jako poczucie bezpieczeństwa państwa, odczuwane przez rząd i naród.

Pojęcie bezpieczeństwa ekonomicznego donosi się do czynników stanowiących ekonomiczne podstawy funkcjonowania gospodarki państwa. Według K. Księżopolskiego bezpieczeństwo ekonomiczne to niezakłócone funkcjonowanie gospodarki, a więc utrzymanie podstawowych wskaźników rozwojowych oraz zapewnienie porównywalnej równowagi z gospodarkami innych państw (Księżopolski 2011, s. 24). Autor wyodrębnia cztery obszary bezpieczeństwa ekonomicznego, które są ze sobą powiązane i zależne od siebie, a mianowicie:

- bezpieczeństwo finansowe,

- bezpieczeństwo energetyczne,

- bezpieczeństwo surowcowe,

- bezpieczeństwo żywnościowe i bezpieczeństwo dostępu do czystej wody.

Funkcjonowanie państwa we współczesnych międzynarodowych realiach politycznych i ekonomicznych wymaga ciągłej uwagi i zdecydowanych działań władz, mających na celu sprostanie zagrożeniom dla szeroko rozumianego bezpieczeństwa kraju.

\section{Współczesne pojęcie surowców strategicznych}


Pojęciem „surowce” określamy materiały do dalszej przeróbki. Ze względu na pochodzenie można je podzielić na:

- surowce mineralne - wszelkiego rodzaju kopaliny,

- surowce pochodzenia roślinnego - uprawy przemysłowe,

- surowce pochodzenia zwierzęcego.

Zgromadzenie wszystkich niezbędnych dla rozwoju gospodarki surowców, w adekwatnej do potrzeb ilości, napotyka (w obecnej sytuacji polityczno-gospodarczej świata) na znaczne trudności. W rezultacie wyodrębniono najważniejszą dla gospodarki grupę surowców, tzw. surowce strategiczne. Wszystkie kraje na świecie, bez względu na stopień rozwoju gospodarczego, wprowadziły regulacje dotyczące ochrony lub reglamentacji w gospodarowaniu tymi surowcami. Chodzi tu o konkretne złoża kopalin i surowce, które uznane zostały za istotne dla rozwoju gospodarki, przemysłu obronnego albo wysokich technologii, np.: lotniczych, kosmicznych czy zbrojeniowych (Galos i in. 2012, s. 43-52).

Zestaw strategicznych dla gospodarki surowców nie jest stały i ulega zmianom w zależności od przyjętego modelu rozwoju, od stopnia ich dostępności i potrzeb systemu obronnego. Najczęściej pojęciem „surowce strategiczne” określamy surowce sprowadzane z zagranicy, ze względu na ich brak w kraju, nawet w postaci zamienników (Stankiewicz 1981, s. 145). Taka interpretacja wydaje się być poprawna, państwa bowiem mają zróżnicowany dostęp do bazy surowcowej i energetycznej. Co dla jednych krajów będzie ogólnie dostępne, dla innych może być surowcem o znaczeniu strategicznym.

Kryteria klasyfikacji surowców mogą być różne, np.: według przeznaczenia albo źródeł pochodzenia. W literaturze terminem „surowce” określa się zamiennie:

- grupę surowców przemysłowych, do dalszego przetworzenia - zalicza się do nich metale, surowce mineralne i paliwa;

- ogół surowców obejmujących surowce pochodzenia organicznego (np. produkty rolne) oraz surowce nieorganiczne (Wojciechowski 1995, s. 972-974).

$\mathrm{W}$ zależności od ich użycia $\mathrm{w}$ różnych procesach produkcyjnych dzielą się na: energetyczne, metaliczne i niemetaliczne.

Kraje należące do UE w dokumentach odnoszących się do surowców często używają zamiennie terminów „strategiczne” albo „krytyczne”. Przyjęto, że pod pojęciem „strategiczne” kryją się surowce o zastosowaniu głównie wojskowym. Materiały niezbędne dla prawidłowego działania gospodarki, których import jest konieczny, często określa się jako krytyczne (Smakowski 2011, s. 60-61).

Takie terminy stosuje się w stosunku do surowców, które nie mają zarówno pierwotnych, jak i wtórnych źródeł na obszarze UE, jak również nie ma możliwości ich produkcji. Za krytyczne uznaje się zwykle surowce o zasadniczym znaczeniu dla gospodarki, do których dostęp związany jest $\mathrm{z}$ bardzo dużym prawdopodobieństwem ograniczenia podaży przy braku własnych zasobów albo wysokim ryzykiem dla środowiska. Analizie podlegają zwykle trzy grupy kryteriów związanych z: ryzykiem ograniczenia podaży (przerwania dostaw), gospodarczymi skutkami ograniczenia podaży i ryzykiem środowiskowym (ograniczenie możliwości produkcji w krajach będących dostawcami). 
Gospodarka zarówno naszego kraju, jak i UE zależna jest w znacznym stopniu od importu głównie metali niezbędnych dla nowoczesnych technologii, takich jak kobalt, platyna, tytan. Duże ryzyko wystąpienia niedoboru w tym asortymencie w dużej mierze wynika z małej liczby państw będących producentami znacznej części tych surowców, np.:

- Rosja: wolfram, platynowce;

- Chiny: fluoryt, antymon, german, gal, grafit, magnez, wolfram, pierwiastki ziem rzadkich;

- Brazylia: tantal, niob;

- Demokratyczna Republika Konga: tantal, kobalt.

Na około 110 surowców mineralnych, które używane są w globalnej gospodarce, jako krytyczne dla gospodarki krajów UE uznano 14. Ujęte na tej liście surowce to głównie metale o zróżnicowanym znaczeniu gospodarczym.

Surowce, których źródła pierwotne i wtórne znajdują się w krajach UE, a mimo to potrzeby na nie w znacznej części pokrywane są importem, określamy jako „surowce deficytowe". Pośród tych surowców znajduje się między innymi kilkanaście metali. Na liście surowców uznanych jako deficytowe dla gospodarki naszego kraju, jak i UE znajdują się między innymi: rudy żelaza, aluminium, mangan, molibden, cyna, nikiel, perlit, lit, talk, skalenie, wollastonit, pirofyllit i inne. Niektóre z nich występują na terenie Polski bądź UE, ale są trudności, aby z istniejących źródeł uzyskać potrzebne surowce w odpowiedniej jakości i ilości.

Na rynki zbytu surowce najczęściej dostarczane są po wstępnej obróbce, a więc przystosowane do zużycia w procesach produkcyjnych.

\section{Zapasy strategiczne - funkcje w gospodarce}

Gospodarka narodowa - rozumiana jako całość zasobów i działań prowadzonych w sferze produkcji, podziału, obiegu i konsumpcji w kraju, służących do zaspakajania potrzeb społeczeństwa w okresie pokoju (Mała encyklopedia ekonomiczna 1974, s. 254) - uwzględnia również potrzeby bezpieczeństwa państwa. W tym celu państwo tworzy rezerwy rzeczowe, a więc wyodrębnia określoną potrzebami część zasobów materialnych, którą gromadzi się z przeznaczeniem dla realizacji szczególnych celów. W sytuacji szybko zmieniającej się rzeczywistości gospodarczej, zarówno w kraju, jak i na świecie, rezerwy strategiczne nabierają szczególnego znaczenia. Stanowią bowiem jeden z najważniejszych elementów bezpieczeństwa państwa.

Zasadniczą rolę $\mathrm{w}$ ich tworzeniu i utrzymaniu odgrywa potencjał ekonomiczny kraju, a więc ogólny poziom zasobów ekonomicznych, które może wytworzyć naród dla realizacji swoich celów - wewnętrznych i zewnętrznych (Rysunek 1). Decyduje on w głównej mierze o możliwościach wykorzystania potencjału narodowego, jego zdolności do szybkiej mobilizacji, a także występujących w tym zakresie ograniczeniach (Balcerowicz (oprac.) 2001, s. 56). W sumie stanowi to pochodną stabilności makroekonomicznej i finansowej, ma również ogromny wpływ na pozycję państwa w społeczności międzynarodowej. 


\section{Zasoby rzeczowe}

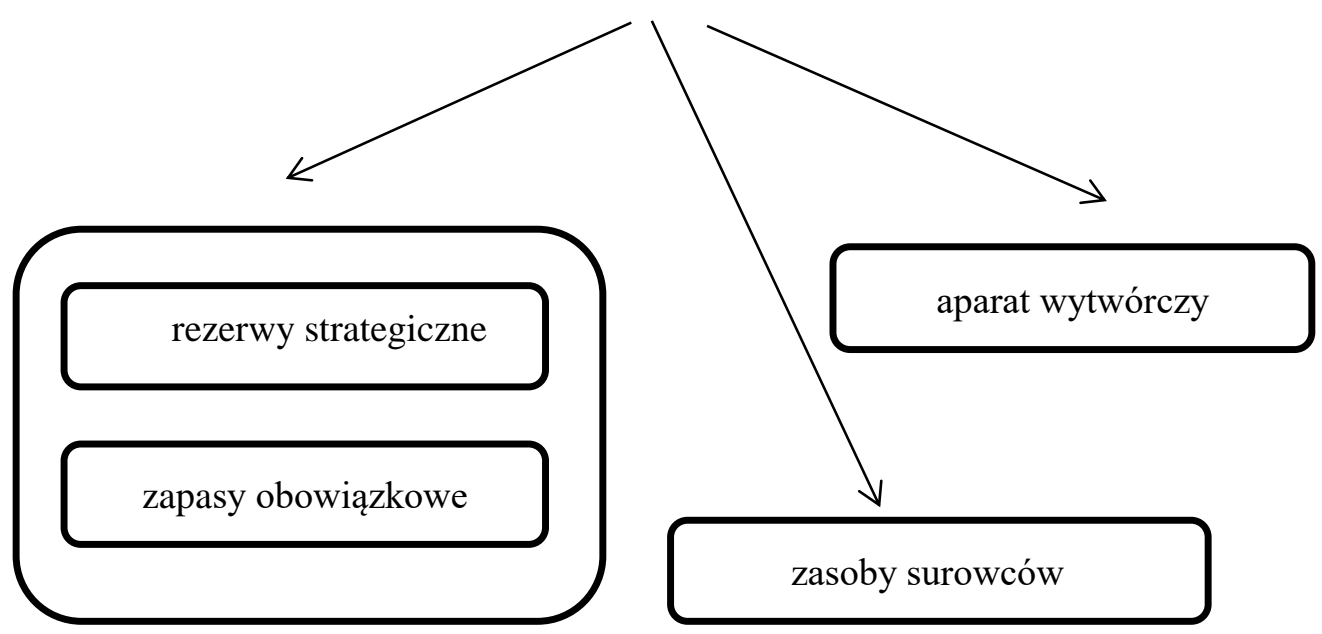

Rysunek 1. Zasoby rzeczowe potencjału gospodarczo-obronnego państwa

Źródło: Opracowanie własne

Ważność rezerw strategicznych wynika $\mathrm{z}$ faktu, iż ich stan warunkuje funkcjonowanie wszystkich pozostałych elementów gospodarki państwa. Utrzymanie ciągłości dostaw paliw to podstawowe zadanie tego działu gospodarki. Według autorów pracy Gospodarka wybranymi zasobami naturalnymi w Polsce a bezpieczeństwo ekonomiczne (Płaczek (red.) 1999, s. 14) ograniczenie dostaw np. gazu lub ropy może spowodować w Polsce bezpośrednie zakłócenia bezpieczeństwa ekonomicznego w postaci paraliżu sektora energetycznego, przemysłowego i transportu. $\mathrm{Na}$ tym tle znaczenie rezerw jawi się z całą złożonością. Gospodarka narodowa jest zasadniczym źródłem zaopatrywania każdego państwa i społeczeństwa w produkty i usługi.

Termin „rezerwy” obejmuje szeroki zakres pojęciowy. Stownik języka polskiego (Doroszewski (red.) 1965, t. 7) pod hasłem „rezerwa” (z łacińskiego „reservo”zachowuję) wyjaśnia, że pod tym pojęciem należy rozumieć:

- w sensie ekonomicznym: zapas zrobiony w przewidywaniu jakiejś potrzeby;

- w sensie wojskowym:

a) stan osobowy przeznaczony do uzupełnienia mobilizowanych jednostek oraz uzupełnienia strat $\mathrm{w}$ jednostkach istniejących,

b) oddział siły zbrojnej pozostawiony w odwodzie.

Z przytoczonej definicji terminu wynika, że pojęcie rezerwy w sensie ekonomicznym oznacza celowo utworzone zapasy i w takim znaczeniu, jeśli chodzi o go-spodarkę materiałową, jest potocznie używane.

Gromadzenie rezerw materiałowych dla zaopatrzenia gospodarki, a w tym i ludności, a także sił zbrojnych, w wypadku zagrożenia bezpieczeństwa państwa, to jedno z najważniejszych zadań gospodarki. Żeby sprostać temu zadaniu, niezbędne 
staje się wcześniejsze tworzenie zapasów i rezerw w ilościach niezbędnych dla przetrwania. Podejmowanie decyzji dotyczących kształtowania poziomu zasobów polega na rozwiązywaniu najważniejszych wzajemnie ze sobą powiązanych problemów:

- Które zasoby mają być gromadzone.

- Jaka ilość zasobów ma być przechowywana.

- Jaki powinien być system rotacji zasobów.

- Kiedy i w jakiej ilości należy uzupełniać zasoby (Rysunek 2).

Utrzymywanie rezerw związane jest $\mathrm{z}$ bardzo dużymi kosztami wiążącymi się zarówno $\mathrm{z}$ ich utworzeniem, jak i utrzymaniem. W znaczącej większości jest to domena budżetu państwa, który nakłady te ponosi. Przyjęto, że nakłady na tworzenie rezerw oraz ich wartość to jednorazowe wydatki budżetowe związane z zakupem określonych materiałów, surowców itp., tworzących rezerwy (składa się na powyższe cena zakupu oraz koszty transportu do miejsc składowania).

Wydatki związane $\mathrm{z}$ gospodarowaniem rezerwami pokrywane są przez budżet państwa i przeznaczone są na sfinansowanie:

- przyrostu i zmiany struktury rezerw, zgodnie z ustaleniami planów tworzenia rezerw,

- kosztów utrzymania i magazynowania rezerw,

- kosztów wymiany (rotacji, odświeżania) rezerw,

- nakładów inwestycyjnych związanych z budową i modernizacją infrastruktury technicznej utrzymywania rezerw.

Wymagany poziom rezerw ustalany jest jedynie dla surowców i produktów, które mają związek z takimi obszarami, jak: obronność kraju, bezpieczeństwo energetyczne, zapewnienie funkcjonowania przemysłu obronnego, pokrycie potrzeb żywnościowych ludności w przypadkach zagrożeń militarnych lub innych trudnych do przewidzenia zdarzeń losowych, np.: choroby, pożary, powodzie. Nieodzownym aspektem związanym ze skutecznym działaniem systemu rezerw jest potrzeba zapewnienia możliwie wysokiego stopnia jego bezpieczeństwa. Problematyka ta powinna zawierać realizację takich przedsięwzięć, jak zabezpieczenie:

- źródeł dostaw (podstawowych i alternatywnych w czasie pokoju i w sytuacjach kryzysowych),

- systemu transportu (przeciwdziałanie przewidywanym zagrożeniom),

- systemu kontroli stanu rezerw (bezpieczeństwo systemu magazynowania i zabezpieczenie przeciwpożarowe),

- miejsc składowania rezerw (poprzez właściwe rozśrodkowanie zmniejszające możliwości ich zniszczenia),

- systemu przepływu informacji i dyspozycji o stanie i ruchu rezerw (Bolkowska, Skowronek 1997, s. 25).

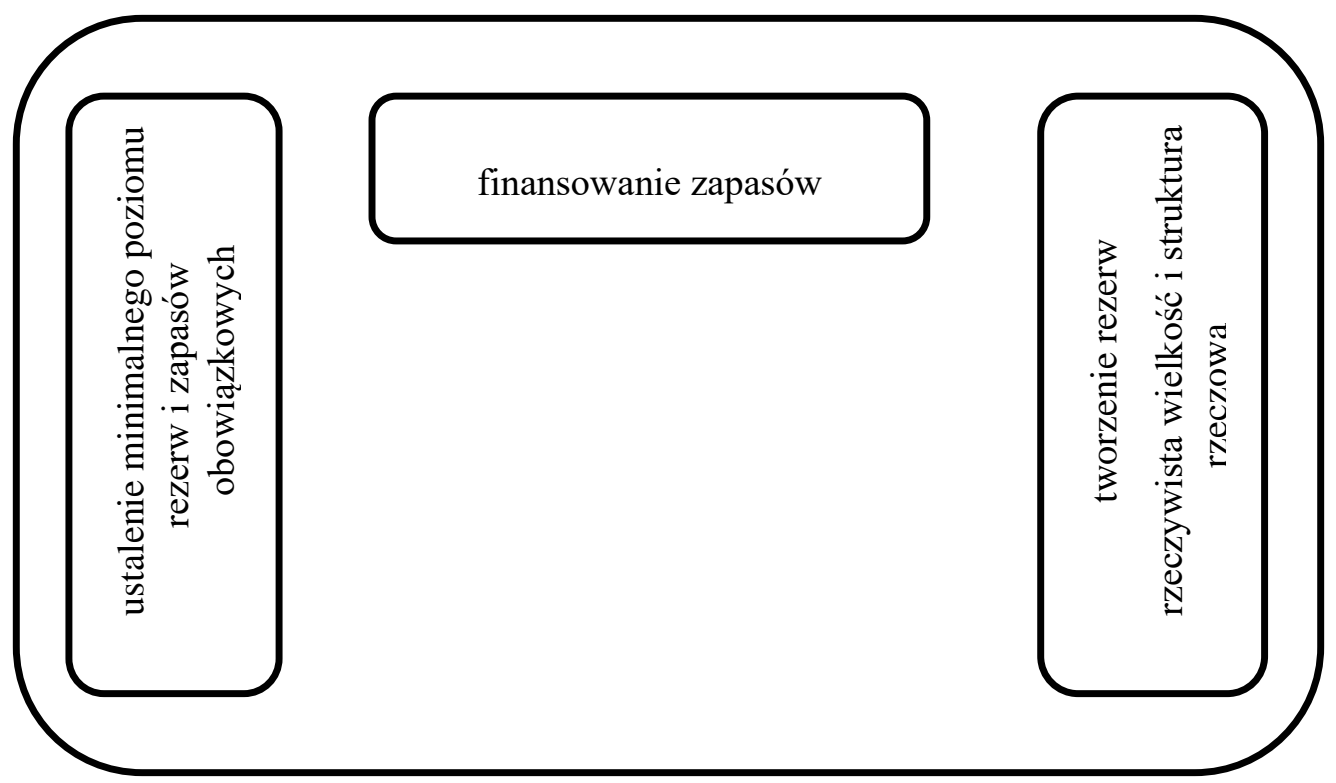




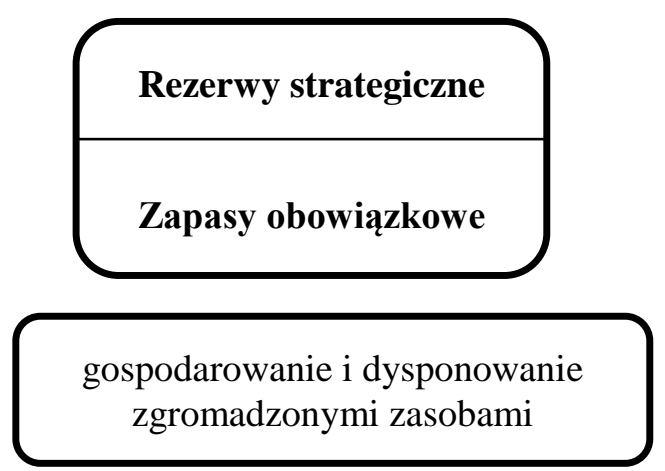

\section{Rysunek 2. Otoczenie decyzyjno-ekonomiczne rzeczowych zapasów państwa}

Źródło: Opracowanie własne na podstawie (Ustawa z 29 października 2010 r. ...; Ustawa z dnia 9 kwietnia 2010 r. ...; Ustawa z dnia 30 maja 2014 r. ...)

Przy ustaleniu struktury rzeczowej oraz określeniu wielkości i poziomu rezerw trzeba zwrócić uwagę, aby asortyment gromadzonych w rezerwach surowców strategicznych z punktu widzenia ich wielkości i poziomu rozpatrywać w trzech zasadniczych grupach - związanych z obronnością, bezpieczeństwem wewnętrznym $\mathrm{i}$ bezpieczeństwem ekonomicznym państwa - w zakresie określonym w ustawie. Ustalając poziom rezerw poszczególnych surowców i produktów, powinno się też uwzględniać międzynarodowe uwarunkowania i zobowiązania - między innymi wymogi stawiane krajom Unii Europejskiej, a także przynależność Polski do NATO.

\section{Znaczenie gospodarcze rezerw}

Gospodarka narodowa naszego kraju w całej swej historii narażona była na różnego rodzaju zakłócenia związane z wydarzeniami międzynarodowymi. Współczesna sytuacja na świecie również jest dynamiczna, pełna konfliktów, nie tylko w wymiarze politycznym lub militarnym, ale przede wszystkim ekonomicznym.

Powody zakłóceń w procesach gospodarczych mogą mieć różne, nie tylko militarne, ale również niemilitarne przyczyny, np.: polityczne, społeczne czy wywołane siłami natury (pożary, susze, powodzie).

Militarne zagrożenie bezpieczeństwa państwa rozumiane jest zwykle jako możliwość użycia przez stronę przeciwną sił i środków mających charakter militarny, a także realizacja zamierzeń zaliczanych przez społeczność międzynarodową do elementów takich zagrożeń, np. utrata suwerenności i integralności terytorialnej w wyniku działań zbrojnych (Huzarski 2009, s. 22).

Zagrożenia niemilitarne w stanie kryzysu to splot zdarzeń mogących doprowadzić do poważnych utrudnień w rozwoju gospodarki państwa, a nawet naruszenia 
lub utraty jego suwerenności i integralności terytorialnej. Celem takich działań jest wymuszenie uległości lub ustępstw. Cel osiągany jest poprzez stosowanie sankcji ekonomicznych albo stosowanie nacisków politycznych, bez użycia sił zbrojnych. Zagrożenia te mogą przyjąć różny wymiar na różnych płaszczyznach:

- na płaszczyźnie politycznej - np.: izolacja polityczna, szantaż polityczny;

- wojna gospodarcza - np. ograniczenie albo zerwanie wymiany handlowej, ograniczenie pomocy finansowej;

- na płaszczyźnie społecznej - zerwanie współpracy technicznej, naukowej, turystycznej, kulturalnej;

- najczęściej - jednocześnie w kilku dziedzinach (Dworecki 1996, s. 21-25).

Wagę zgromadzonych rezerw rzeczowych w zakresie złagodzenia albo wyeliminowania negatywnych skutków różnego rodzaju trudnych do przewidzenia zdarzeń nadzwyczajnych trudno przecenić. Walka ze skutkami kataklizmów, które miały miejsce w ostatnim czasie, choćby powódź w 2007 roku, jednoznacznie pokazuje przydatność rezerw rzeczowych. W takich szczególnych przypadkach, używając ich, rząd może wpływać na przebieg procesów gospodarczych, zapobiegając w ten sposób panice na rynku, np.: nadmiernemu wzrostowi cen albo spekulacji.

\section{Podsumowanie}

Kryzys gospodarczy wywołany z powodów politycznych jest z reguły zamierzonym efektem i świadomym działaniem przywódców państw ościennych bądź też ponadnarodowych organizacji gospodarczych. Z całą ostrością pokazują to ostatnie konflikty międzynarodowe, mające również swój wymiar gospodarczy. Szczególnie groźne dla naszego kraju są konflikty za wschodnią granicą. Ich reperkusje mają groźny, bezpośredni wpływ na gospodarkę Polski. Jeden z licznych konfliktów energetycznych między Ukrainą a Rosją zaowocował realną możliwością wstrzymania przez Rosjan przesyłu ropy naftowej rurociągiem Jamał, dostarczającym ten surowiec do rafinerii w Europie Środkowej.

Obecne sankcje ekonomiczne nałożone na Rosję przez Unię Europejską oraz Stany Zjednoczone i rosyjska odpowiedź w postaci embarga na towary i żywność z państw Unii zmieniły obowiązujące do tej pory w handlu międzynarodowym zasady wymiany towarowej. Dotychczas jednak swym zasięgiem nie objęły międzynarodowych umów dotyczących dostaw ropy naftowej czy gazu. Natomiast rosyjskie embargo nałożone na produkty żywnościowe z Unii Europejskiej uderzyło dotkliwie w polską gospodarkę, szczególnie w przemysł spożywczy.

W przypadku odcięcia dostaw surowców energetycznych przez stronę rosyjską deficyt trwający do 90 dni na polskim rynku krajowym można zaspokoić poprzez uruchomienie alternatywnych metod zaopatrzenia. Najważniejszym elementem w tym przypadku będą zgromadzone przez nasz kraj rezerwy strategiczne ropy naftowej i gazu.

Narastające zjawisko globalizacji w gospodarce światowej to główna przyczyna zacieśniania więzi i współzależności między gospodarkami poszczególnych krajów. 
Powoduje to, że zarówno przepływy finansowe, jak i procesy gospodarcze niejednokrotnie zyskują wymiar ponadnarodowy. Wskutek tego gospodarki narodowe poszczególnych państw są coraz bardziej zależne od czynników zewnętrznych.

Usunięcie zakłóceń w normalnym funkcjonowaniu gospodarki, likwidacja spowodowanych szkód i przywrócenie normalnego stanu wymagają szybkich działań i zwiększonych nakładów. Możliwość takiego działania daje państwu zgromadzenie odpowiedniego zapasu rezerw strategicznych. Ma to zasadniczy wpływ zarówno na utrzymanie wymaganego poziomu bezpieczeństwa kraju, jak również zapewnienia niezakłóconej egzystencji obywatelom.

W światowej polityce gospodarczej w ostatnich latach coraz częściej jako broń stosuje się rozgrywkę surowcami, a więc niemilitarne uderzenie osłabiające gospodarkę przeciwnika. Konflikty międzynarodowe w wymiarze gospodarczym wyraźnie wskazują, że nie ma alternatywy dla gromadzenia rezerw surowców strategicznych. Rezerwy finansowe, mimo swej istotnej wagi, nie mogą zastąpić wcześniej utworzonych odpowiednio do możliwości, potrzeb i przeznaczenia rezerw rzeczowych. Ich tworzenie i utrzymywanie jest podyktowane obiektywną koniecznością.

\section{Literatura}

1. Balcerowicz B. (oprac.) (2001), Stownik terminów z zakresu bezpieczeństwa narodowego, AON, Warszawa.

2. Bolkowska Z., Skowronek C. (1997), Rezerwy państwowe. Funkcje, organizacja, ekonomika, WSBiA, Warszawa.

3. Doroszewski W. (red.), Stownik języka polskiego, PWN, Warszawa 1965.

4. Dworecki S. (1996), Od konfliktu do wojny, BUWiK, Warszawa.

5. Galos K., Nieć M., Radwanek-Bąk B., Smakowski T., Szmałek K. (2012), Bezpieczeństwo surowcowe Polski w Unii Europejskiej i na świecie, „Biuletyn Państwowego Instytutu Geologicznego", nr 452, s. 43-52.

6. Huzarski M. (2009), Zmienne podstawy bezpieczeństwa i obronności państwa, AON, Warszawa.

7. Koziej S. (2011), Bezpieczeństwo: istota, podstawowe kategorie i historyczna ewolucja, „Bezpieczeństwo Narodowe” II, nr 18, s. 19-39.

8. Księżopolski K.M. (2011), Bezpieczeństwo ekonomiczne, Dom Wydawniczy Elipsa, Warszawa.

9. Mała encyklopedia ekonomiczna, PWE, Warszawa 1974.

10. MON (1970), Mała encyklopedia wojskowa, t. 2, Ministerstwo Obrony Narodowej, Warszawa.

11. Płaczek J. (red.) (1999), Gospodarka wybranymi zasobami naturalnymi w Polsce a bezpieczeństwo ekonomiczne, kryptonim „Zasoby”, AON, Warszawa.

12. Smakowski T.J. (2011), Surowce mineralne - krytyczne czy deficytowe dla gospodarki UE i Polski, „Zeszyty Naukowe Instytutu Gospodarki Surowcami Mineralnymi i Energii Polskiej Akademii Nauk", nr 81, s. 59-68.

13. Stankiewicz W. (1981), Ekonomika wojenna, Ministerstwo Obrony Narodowej, Warszawa.

14. Ustawa z dnia 29 października 2010 r. o rezerwach strategicznych (Dz.U. $2010 \mathrm{nr} 229$ poz. 1496, z późn. zm.).

15. Ustawa z dnia 30 maja 2014 r. o zmianie ustawy o zapasach ropy naftowej, produktów naftowych i gazu ziemnego oraz zasadach postępowania w sytuacjach bezpieczeństwa paliwowego państwa i zakłóceń na rynku naftowym oraz niektórych innych ustaw (Dz.U. 2014 poz. $1806,1897,1812,1814)$. 
16. Ustawa z dnia 9 kwietnia 2010 r. o zmianie ustawy o zapasach ropy naftowej, produktów naftowych, gazu ziemnego oraz postępowania w sytuacjach zagrożenia bezpieczeństwa paliwowego państwa i zakłóceń na rynku naftowym (Dz.U. $2010 \mathrm{nr} 81$ poz. 532).

17. Wojciechowski H. (1995), Surowce, [w:] Pomykało W. (red.), Encyklopedia biznesu, t. 2, Fundacja Innowacja, Warszawa.

\title{
STRATEGIC RAW MATERIALS IN THE COUNTRY'S ECONOMIC SECURITY
}

\begin{abstract}
Without the access to the raw materials, high rate of economic development and national security of any country is impossible. The concept of economic security relates to the factors which constitute the economic base of the country. In order to maintain the unperturbed development of the economy, the state creates reserves. It identifies part of available resources, based on needs, and stores them with intention to fulfill specific purposes. In the situation where economic environment is rapidly changing, both domestically and internationally, strategic reserves take on a special significance. They are in fact one of the most important elements of national security. A set of resources of strategic importance for the economy is not constant and is evolving, depending on the adopted model of development as well as their degree of availability and the needs of the defense system. In the world economic policy in recent years, raw materials are often used as a weapon, instead of a military blow, as the as a means of weakening opponent's economy. The aim of the article is to show the key role of strategic raw materials to ensure national and economic security and thus undisturbed development of the economy of the country.
\end{abstract}

Keywords: national security, economic security, economic conflicts, strategic reserves, raw materials: strategic, critical, scarce 